\title{
Canadian Sovereignty Linked to Energy Development in the Arctic
}

\author{
by Benoît Beauchamp and Rob Huebert
}

I NDUSTRY IS ABOUT TO EMBARK SERIOUSLY On eXploration and probable development of Canada's Arctic energy resources. The price of natural gas has recovered from its recent lows and is now on the upswing, with no end in sight. With conventional natural gas production already in decline in the mature Western Canada Sedimentary Basin, no one can predict when and where the price of gas will stabilize. Oil has long passed the $\$ 100$ psychological barrier and currently sells at nearly $\$ 140$ a barrel, getting ever closer, in absolute dollars, to levels not reached since the oil shocks of the 1970s. The world's largest oilfields are in decline, starting with Saudi Arabia's mammoth Ghawar field, one of many giant oil pools from Mexico, Russia, and the Middle East discovered during the heyday of hydrocarbon exploration in the 1960s and 1970s. Conventional supplies are declining as China and India grow at breakneck pace, and our American neighbour shows no sign of losing its thirst for energy, although the ongoing woes of the U.S. economy are likely to reduce energy consumption in the short term.

Against this backdrop, only remote frontier areas such as the Canadian Arctic offer any hope for large new conventional discoveries. The North American Arctic is clearly in the cross hairs of the industry, and it is only a matter of time before the starting gun of a new era of energy exploration in the Far North is heard in corporate offices. While supply, demand, and the price of commodities will loom large in the mind of industry decision makers the day they decide to go North, many other factors will also have to be examined before industry commits billions of dollars in capital investment to go after Arctic resources. One of the least worrisome aspects of Arctic energy development is probably the resource itself. Large gas discoveries were made during the first round of exploration three decades ago. There is enough gas in the three large fields of the Mackenzie Delta-Taglu, Niglintgak, and Parsons Lake-to feed the yet elusive Mackenzie Valley pipeline for at least 20 years. Huge quantities of gas were also found in the Arctic Islands, and a number of studies suggest that shipping this gas to market is indeed possible. While oil was the prime reason for the early round of exploration, the paucity of sizeable oil discoveries from these initial efforts was disappointing. However,
Devon Canada's discovery of 250 million barrels beneath the Beaufort Sea in 2006 and Imperial Oil and Exxon Mobil Canada's massive $\$ 585$ million bid for a huge offshore block in 2007 signaled that the Arctic oil flame may have been rekindled. Confirmation came in June of this year with British Petroleum's record-breaking \$1.2 billion bid for offshore land dispositions in the Beaufort Sea adjacent to the Imperial-Exxon-Mobil acquisitions.

Companies are now preparing for the move northward. These include ConocoPhillips Canada and Chevron Canada, which acquired some offshore land dispositions in 2007 and 2008. Petro-Canada is also a key player, as it owns large portions of the Significant Discovery Licenses in the Arctic Islands. However, beyond finding the resources in the ground, above or below the sea, companies still face a seemingly endless list of challenges: a regulatory process viewed as overly complicated and in the thrall of too many interests, an environment that is harsh and unforgiving, political ramifications that seem far more complicated than they used to be, and a warming climate that is playing havoc with infrastructures. On that front, and conversely to the popular belief that the melting of Arctic ice due to global warming will be a boon for exploration, there is much uncertainty about the extent to which a warming Arctic environment will add significant cost to the already hefty bill for conducting exploration in the Far North. Still, the challenges may not be insurmountable when compared to those posed by the earth's few other remaining areas with substantial hydrocarbon potential. These are often war-torn countries, forsaken by democracy, where corruption and terrorism rule the day. In the end, the regulatory problems in the North may be insignificant when compared to dealing with warlords or with governments willing to renege on sealed deals and signed contracts. Going after the few giant conventional hydrocarbon fields left to be discovered will be costly and risky.

These current and anticipated developments are intertwined with, and are bound to exacerbate, the issue of Canadian Arctic sovereignty, one of the most emotionally charged and misunderstood issues surrounding the Canadian North. Arctic sovereignty is truly about control. No one challenges Canada's control over its Arctic lands. The one minor exception is the ownership of Hans Island, a tiny 
circular piece of rock lost in the middle of Nares Strait between Greenland and Ellesmere Island that both the Danes and the Canadians call their own.

However, Canada is seriously challenged over the control of what it calls its own Arctic waters. Both Americans and Europeans hold the contentious position that the Northwest Passage is a strait to be used for international navigation. Canada, in contrast, claims that these are internal waters. This disagreement is only about the control of international shipping-but this is still a critically important issue for Canada. If the American position is correct, international shippers-including oil and gas tankers-would not have to ask for Canadian permission to transit these waters. International rather than Canadian rules would thus govern environmental protection and ship construction. If Canada is correct, then international shippers would have to follow Canadian laws and ultimately seek Canadian permission before entering the Passage. Thus, the issue of Arctic sovereignty is very much an environmental issue, as well as an economic and political one.

The Americans may well need to look to seabound means of transporting their oil and gas out of the Arctic. For the time being, a major gas pipeline is being considered to carry stranded gas from Prudhoe Bay across the State of Alaska and the Yukon Territory and ultimately to southern markets. But competition from the Mackenzie Valley pipeline, escalating construction costs, and the difficulties of raising risk capital at a time of a global credit crunch, may well conspire to force key stakeholders to look for alternatives. Likewise, permafrost destabilization may render the existing oil pipeline very costly to operate and maintain in the face of climate change. The resource companies may well find out that shipping the resources by sea is less costly and entails fewer risks than the overland pipeline options. New shipping technology such as that currently being developed in South Korea makes this scenario increasingly likely. In particular, the South Koreans have become world leaders in the construction of ice-strengthened oil and gas tankers. It is therefore possible that the Americans may want to revisit their decision not to ship Alaskan oil by tanker. Before the Americans seriously consider the maritime transportation possibilities, some agreement with Canada on the status of the Northwest Passage needs to be reached. Otherwise, there is no reason to believe that there would not be a repeat of the controversy that occurred in 1969, when the Americans sent the supertanker Manhattan through the Passage without first requesting permission to enter what Canada considers its internal waters.

Canada also faces international challenges to both its eastern and western Arctic maritime boundaries. The eastern Arctic maritime dispute with Denmark in Nares Strait is relatively insignificant and is unlikely to involve oil and gas development. Far more significant is the issue with the Americans that revolves around the western maritime boundary in the Beaufort Sea. The area in dispute is extensive and probably contains significant oil, gas, and gas hydrate resources. The question at the core of this issue is which of the two countries, Canada or the United States, will oversee resource exploitation in this offshore sector and therefore receive the economic benefits of this development. A joint management protocol to develop energy resources in the disputed zone would dispel the more negative elements of this disagreement.

Canada will also face disputes over the claim to its northern maritime boundary. Currently, the federal government is attempting to define the outer limits of its northern continental shelf. Under the new terms of international law - the United Nations Convention on the Law of the Sea (Article 76) - all nations now have the right to extend their control over their maritime seabed if they can show that it is part of an extended continental shelf. There is a growing consensus that a large part of the Arctic Ocean may be an extension of the North American and Asian continental shelves. If this is the case, then the challenge for all Arctic nations will be to determine where their claims begin and end. During the summer of 2007, the Russians demonstrated, with their much-publicized expedition to plant the Russian flag on the North Pole's seabed, that they will be pursuing their claims in an aggressive fashion. Again, at the core of this issue will be the control of energy resources found under the seabed, although it is by no means clear how much of these resources, if any at all, lies beneath the outer reaches of the Arctic continental shelves and beneath the various linear geological elements such as the Lomonosov Ridge that crisscrosses the Arctic Ocean floor. When it comes to the riches beneath the North Pole, everyone's guesses are equally good. But as recently indicated by the U.S. Geological Survey, the Arctic as a whole may contain as much as 90 billion barrels of undiscovered conventional oil and 1670 trillion cubic feet of gas (Bird et al., 2008). These numbers are sure to awaken the territorial ambitions of Arctic nations.

It is obvious that the issues of Arctic energy development and Arctic sovereignty are closely linked. The discovery of the Prudhoe Bay oil field in 1968, which unleashed an exploration frenzy in the Arctic, was followed a year later by the Manhattan controversy, which triggered the sovereignty dispute. With the collapse of the oil price in the early 1980s, the oil companies packed their drilling rigs and went home. Both industry and governments lost their northern appetite for nearly two decades. When no one was talking about actually developing Arctic resources, the many sovereignty issues could be and were ignored. But the Canadian government knew it would have to deal with these issues someday. Amazingly, that day is only now arriving, despite the high profile of the Arctic resulting from an unprecedented convergence of issues and the growing interest in the discovered and undiscovered resources of the Far North. The current impact of these sovereignty disputes may hurt Canada's relations with its Arctic neighbours - the very same neighbours with which Canada needs to cooperate in order to develop its northern 
resources in the best environmentally and economically sustainable fashion.

Any political uncertainty is yet another significant barrier affecting industry's ability to operate in these already formidable environments. Thus it is in the Canadian government's interests to resolve these disputes as quickly as possible. It needs to do so in a manner that ensures Canadian interests and values are protected in the Arctic. But it also needs to do so in a manner that will allow for long-term cooperation with Canada's northern neighbours as they too develop their natural resources in the region.

\section{REFERENCE}

BIRD, K.J., CHARPENTIER, R.R., GUATIER, D.L., HOUSEKNECHT, D.W., KLETT, T.R., PITMAN, J.K., MOORE, T.E., SCHENK, C.J., TENNYSON, M.E., and WANDREY, C.J. 2008. Circum-Arctic resource appraisal: Estimates of undiscovered oil and gas north of the Arctic Circle. U.S. Geological Survey Fact Sheet 2008-3049. 4 p. Available online at http://pubs.usgs.gov/fs/2008/3049/.

Dr. Benoît Beauchamp is executive director of the Arctic Institute of North America and a professor in the Department of Geoscience at the University of Calgary. Dr. Rob Huebert is an associate professor in the Department of Political Science at the University of Calgary. He is also the associate director of the Centre for Military and Strategic Studies. 